\title{
OÚRICUR'
}

\section{TIPOS DE EXPLANTES E CONCENTRAÇÃO DE BAP (6-BENZILAMINOPURINA) NO ESTABELECIMENTO IN VITRO DE ANGICO-VERMELHO}

\author{
Jean Santana Miranda'; Adriana da Luz Barros Santana ${ }^{3}$; Alessandro Rosa Nascimento ${ }^{4}$; \\ Olorounchola David Didolanvi ${ }^{5}$; Anna Christina Passos Menezes ${ }^{6^{*}}$; Erifranklin Nascimento \\ Santos ${ }^{7}$; Ana Valéria Vieira de Souza ${ }^{8}$
}

\footnotetext{
${ }^{1}$ Graduado em Engenharia Agronômica, Universidade do Estado da Bahia - UNEB, Departamento de Tecnologia e Ciências Sociais - DTCS, Campus III; Juazeiro, Bahia; E-mail: jean.s.m@hotmail.com. 2Pós-Graduada em Agronomia/Produção Vegetal; Universidade Federal do vale do São Francisco UNIVASF, Campus Ciências Agrárias; Petrolina, Pernambuco. E-mail: adriana.I.barrossantana@gmail.com ${ }^{3}$ Estudante do curso de Engenharia Agronômica; UNEB, DTCS, Campus III; Juazeiro, Bahia. Av. Edgar Chastinet, Bairro São Geraldo, Juazeiro-Ba. E-mail: sd282195@gmail.com

${ }^{4}$ Estudante do curso de Engenharia Agronômica; UNEB, DTCS, Campus III; Juazeiro, Bahia. Av. Edgar Chastinet, Bairro São Geraldo, Juazeiro-Ba. Email: alessandro7600@hotmail.com

${ }^{5}$ Professora Titular do curso de Engenharia Agronômica; Universidade do Estado da Bahia, Departamento de Tecnologia e Ciências Sociais, Campus III; Juazeiro, Bahia. Av. Edgar Chastinet, Bairro São Geraldo, Juazeiro-Ba. E-mail: amenezes@uneb.br

${ }^{6}$ Pós-Graduado em Agronomia. Universidade Federal da Paraíba, Campus II. E-mail: franklin.ns.agro@gmail.com

${ }^{7}$ Engenheira Agrônoma, D.Sc. em Horticultura, pesquisadora da Embrapa Semiárido, Petrolina, PE. E-mail: ana.souza@embrapa.br

Recebido: 28.09.2020 Aceito: 17.12 .2020

https://doi.org/10.29327/ouricuri.10.1-8
}

Resumo: O angico-vermelho (Anadenanthera macrocarpa (Benth.) Brenan - Fabaceae) é uma espécie da caatinga, com ampla utilização na medicina popular, melífera, na obtenção de taninos e recuperação de áreas degradadas. O objetivo deste trabalho foi avaliar a influência do tipo de explante e de diferentes concentrações de BAP (6-benzilaminopurina) no estabelecimento in vitro do angico-vermelho. Segmentos cotiledonares e nodais foram colocados em meio Murashige e Skoog (MS) suplementado com diferentes concentrações de BAP. No experimento foi utilizado o Delineamento Inteiramente Casualizado (DIC) em esquema fatorial 2x4 (dois tipos de explantes e quatro concentrações de BAP) com duas repetições e dez unidades experimentais por repetição. Avaliou-se o número de explantes responsivos, número de brotações por explante, número de gemas por explantes, além do total de explantes que apresentaram calos, oxidação e contaminação. O maior número de brotos por explante foi observado no tratamento utilizando o segmento cotiledonar tratado com $2 \mathrm{mg} \mathrm{L}^{-1}$ de BAP. Houve uma tendência crescente de aumento do número de gemas por explante até a concentração de $1 \mathrm{mg} \mathrm{L}^{-1}$ de BAP para o segmento cotiledonar. No segmento nodal, o número de gemas cresceu de acordo com o aumento da concentração de BAP. O uso de BAP aumentou a quantidade de brotações por explante regenerado.

Palavras-chave: Micropropagação; Espécies Florestais; Caatinga.

\section{EXPLANTS TYPES AND CONCENTRATION OF BAP (6-BENZYLAMINOPURINE) ON THE IN VITRO ESTABLISHMENT OF ANGICO-RED}

\begin{abstract}
The red angico (Anadenanthera macrocarpa (Benth.) Brenan - Fabaceae) is a caatinga species, widely used in folk medicine, meliferous, in obtaining tannins and recovering degraded areas. The aim of this work was to evaluate the influence of the explant type and different BAP (6benzylaminopurine) concentrations on the in vitro establishment of red angico. Cotyledonary and nodal segments were placed in MS medium supplemented with different concentrations of BAP.
\end{abstract}

Revista Ouricuri, Juazeiro, Bahia, v.10, n.1. p.001-008. jan./jul., 2020.

http://www.revistas.uneb.br/index.php/ouricuri | ISSN 2317-0131 
In the experiment, was used completely randomized design (DIC) in a $2 \times 4$ factorial scheme (two explants types and four concentrations of BAP) with two repetitions and ten experimental units per repetition. The number of responsive explants, number of sprouts per explant, number of buds per explant were evaluated, in addition to the total explants that presented calluses, oxidation and contamination. The largest number of shoots per explant was observed in the treatment using the cotyledonary segment treated with $2 \mathrm{mg} \mathrm{L}^{-1}$ of BAP. There was an increasing tendency to increase the number of buds per explant up to the concentration of $1 \mathrm{mg} \mathrm{L}^{-1}$ of BAP for the cotyledonary segment, in the nodal segment, the number of buds increased according to the increase in the concentration of BAP. The use of BAP increased the number of shoots per regenerated explant.

Keywords: Micropropagation; Forest Species; Caatinga.

\section{TIPO DE EXPLANTE Y CONCENTRACIÓN DE BAP (6-BENCILAMINOPURINA) EN EL ESTABLECIMIENTO IN VITRO DE ANGICO-RED}

Resumen: El angico rojo (Anadenanthera macrocarpa (Benth.) Brenan - Fabaceae) es una especie de caatinga, muy utilizada en la medicina popular, melífera, en la obtención de taninos y recuperación de áreas degradadas. El objetivo de este trabajo fue evaluar la influencia del tipo de explante y de diferentes concentraciones de BAP (6-bencilaminopurina) sobre el establecimiento in vitro de angico rojo. Se colocaron cotiledones y segmentos nodales en medio MS suplementado con diferentes concentraciones de BAP. En el experimento se utilizó un diseño completamente aleatorizado (DIC) en un esquema factorial $2 \times 4$ (dos tipos de explantes y cuatro concentraciones de BAP) con dos repeticiones y diez unidades experimentales por repetición. Se evaluó el número de explantes sensibles, número de brotes por explante, número de yemas por explante, además del total de explantes que presentaron callos, oxidación y contaminación. El mayor número de brotes por explante se observó en el tratamiento con cotiledón de seguimiento tratado con 2 mg $\mathrm{L}^{-1}$ de BAP. Hubo una tendencia creciente a incrementar el número de yemas por explante hasta la concentración de $1 \mathrm{mg} \mathrm{L}^{-1}$ de BAP para el segmento cotiledonario, en el segmento nodal, el número de yemas aumentó según el aumento en la concentración de BAP. El uso de BAP aumentó el número de brotes por explante regenerado.

Palabras clave: Micropropagación; Especies Forestales; Caatinga.

\section{INTRODUÇÃO}

A Anadenanthera macrocarpa também conhecida como angico é uma planta que pode atingir 20 metros de altura. Seus ramos novos podem apresentar espinhos. Sua ocorrência vai desde o Nordeste do país até São Paulo e Mato Grosso do Sul. Sua madeira é muito pesada e de grande durabilidade sob condições naturais. A madeira é própria para construção civil e naval, confecção de dormentes e carpintaria, e muito usada em curtume pela grande quantidade de tanino presente na casca. Apresenta um rápido crescimento, podendo ser aproveitada com sucesso para reflorestamentos de áreas degradadas (Lorenzi, 2002). Devido à sua diversidade de potencial de uso, o angico-vermelho tem sofrido frequente exploração predatória por meio da pressão antrópica, o que aponta para a necessidade de alternativas sustentáveis de cultivo, que viabilizem sua reposição em ambiente natural em um curto espaço de tempo.

A cultura de tecidos se enquadra nos métodos de propagação vegetativa (Hoppen, 2011). Para Soomro e Menon (2007), este método fornece uma alternativa para plantas que são difíceis de serem propagadas e que têm um longo período de cultivo ou baixo rendimento de produto. $\mathrm{Na}$ cultura de tecidos, a micropropagação é uma técnica de multiplicação assexuada, conduzida sob 
condições satisfatórias de assepsia, nutrição e fatores como fotoperíodo e temperatura. Nessa técnica, os explantes das matrizes elites são induzidos à multiplicação celular in vitro, mediada por fitorreguladores, produzindo grande quantidade de novos indivíduos, genotípica e fenotipicamente idênticos. O fundamento básico da micropropagação é a totipotência celular, segundo a qual, qualquer célula viva no organismo vegetal contém a informação genética necessária à regeneração de uma planta completa (Fehér et al., 2003).

$\mathrm{Na}$ micropropagação de uma espécie, o primeiro passo é o estabelecimento in vitro de plantas, que se inicia com a seleção dos explantes mais adequados. Diversos explantes podem ser utilizados para iniciar a propagação in vitro de uma planta. $\mathrm{Na}$ seleção desses, devem ser considerados aspectos, como o nível de diferenciação do tecido utilizado e a finalidade da micropropagação (Grattapaglia e Machado, 1999). Quanto a fonte do explante, normalmente é observado maior sucesso na resposta morfogenética se for utilizado explantes de tecidos jovens, os quais possuem maior competência organogênica. Explantes que contém tecidos meristemáticos são preferíveis, sendo encontrados em gemas caulinares apicais e axilares.

Alguns estudos com espécies lenhosas têm utilizado para a indução de brotações, explantes de segmentos nodais apicais e/ou cotiledonares (Kielse et al., 2009; Costa et al., 2010) e outros, utilizando cotilédones (Rodrigues et al., 2009) e hipocótilos (Cerdas e Gusman, 2004).

O crescimento e a organogênese in vitro são altamente dependentes da interação entre as substâncias de crescimento que ocorrem naturalmente na planta (hormônios), e os análogos sintéticos (reguladores de crescimento), os quais são adicionados ao meio de cultura (George, 2008).

Complementando as substâncias biossintetizadas pelas células, os reguladores de crescimento adicionados ao meio de cultura, em concentrações específicas, desempenham um papel fundamental no crescimento e morfogênese em cultura de tecidos (Pierik, 1990; Flores et al., 1998). A adição desses fitorreguladores tem o objetivo principal de suprir as possíveis deficiências dos teores endógenos nos explantes que se encontram isolados nas regiões produtoras da planta matriz (Skoog e Miller, 1957; George, 1993). As citocininas estimulam a divisão celular, bem como, a indução e a proliferação de brotações adventícias (Figueiredo, 2009). Em cultura de tecidos, as citocininas mais comumente usadas são cinetina (CIN), 6-benzilaminopurina (BAP), zeatina (ZEA), isopenteniladenina (2ip) e thidiazuron (TDZ). Estes componentes direcionam o metabolismo do explante para o processo desejado e os efeitos observados quanto às respostas das células, tecidos e órgãos in vitro, variam de acordo com as condições ambientais, o tipo do explante e o genótipo da planta (Pasqual, 2001).

Considerando a importância da espécie $A$. macrocarpa, o presente trabalho teve como objetivo avaliar o efeito tipo de explante e de diferentes concentrações de 6-benzilaminopurina (BAP) no estabelecimento in vitro do angico-vermelho. 


\section{MATERIAL E MÉTODOS}

O experimento foi realizado no Laboratório de Biotecnologia da Universidade do Estado da Bahia - UNEB, Campus III. Foram utilizados como explantes segmentos cotiledonares e nodais de plantas germinadas in vitro com idade fisiológica de 15 dias. Para obtenção das plântulas assépticas, as sementes de angico-vermelho foram colocadas para germinar in vitro. Inicialmente foram submetidas ao processo de desinfestação em câmara de fluxo laminar, imersas em álcool $70 \%$ (v/v) por $1 \mathrm{~min}$, em solução de hipoclorito de sódio 2,5\% por $15 \mathrm{~min}$ e em seguida submetidas a três enxagues em água destilada e autoclavada, com duração de 3 min cada. Em seguida, as sementes foram colocadas em frascos contendo $30 \mathrm{~mL}$ do meio Murashige e Skoog (MS) (1962), $\mathrm{pH}$ aferido para 5,7 - 5,8, solidificado com $7 \mathrm{~g} \mathrm{~L}^{-1}$ de ágar, suplementado com $30 \mathrm{~g} \mathrm{~L}^{-1}$ de sacarose e previamente autoclavado. Os frascos foram mantidos em sala de crescimento com temperatura de $25 \pm 2{ }^{\circ} \mathrm{C}$, fotoperíodo de $16 \mathrm{~h}$ e intensidade luminosa de $36 \mu \mathrm{mol} . \mathrm{m}^{-2} . \mathrm{s}^{-1}$.

Em seguida, as plantas foram submetidas a um processo de lavagem e desinfestação, a fim de remover os resquícios do substrato utilizado para a germinação. Para isso, foram imersas em álcool $70 \%$ durante $1 \mathrm{~min}$, em hipoclorito de sódio $1 \%$ acrescido com 3 gotas do agente emulsionante tween 20 durante 5 min, e enxaguadas em água destilada e autoclavada em três lavagens, com duração de 3 min cada.

Após esse procedimento, segmentos nodais com uma gema axilar e cotiledonares medindo aproximadamente $2 \mathrm{~cm}$ de comprimento, foram colocados em tubos de ensaio contendo $20 \mathrm{~mL}$ de meio de cultura MS, com pH aferido para 5,7 - 5,8 e suplementado com $30 \mathrm{~g} \mathrm{~L}^{-1}$ de sacarose, $7 \mathrm{~g} \mathrm{~L}^{-}$ ${ }^{1}$ de ágar e quatro diferentes concentrações de BAP: 0,0; 0,5; 1 ; e 2 mg L-1.

$O$ delineamento experimental utilizado foi o inteiramente casualizado, em um esquema fatorial $2 \times 4$ (dois tipos de explantes e quatro diferentes concentrações de BAP), com oito tratamentos e duas repetições, sendo cada repetição composta por 10 unidades experimentais (frascos). Os frascos contendo os explantes foram mantidos em sala de crescimento com as condições ambientais semelhantes às descritas anteriormente.

Após 30 dias, procedeu-se à avaliação para as seguintes variáveis: número de explantes responsivos, isto é, que formaram brotos, número de brotações por explante, número de gemas por explantes, além do total de explantes que apresentaram calos, oxidação e contaminação.

Os dados foram analisados por meio do software Assistat versão 7.7 (Silva, 2017) e submetidos ao teste de Tukey ao nível de $5 \%$ de probabilidade.

\section{RESULTADOS E DISCUSSÃO}

Não foi observado efeito significativo para percentagem de oxidação, contaminação e explantes com calos na base em função do tipo de explante e das concentrações de BAP (Tabela 1). É observado na Tabela 1, que independentemente do tipo de explante e concentração do BAP, houve formação de calos. 
Os resultados observados para oxidação demonstram que a espécie em estudo pode ser multiplicada in vitro sem a necessidade da utilização de substâncias antioxidantes.

Tabela 1. Percentagem de oxidação, contaminação e explantes com calos na base.

\begin{tabular}{ccccccc} 
& \multicolumn{3}{c}{ Segmento Cotiledonar } & \multicolumn{3}{c}{ Segmento Nodal } \\
\cline { 2 - 5 } Concentrações de & Oxidação & Contaminação & Calos & Oxidação & Contaminação & Calos na \\
BAP $(\mathrm{mg} / \mathrm{L})$ & $(\%)$ & $(\%)$ & na & $(\%)$ & $(\%)$ & base (\%) \\
& & & base & & &
\end{tabular}

\begin{tabular}{ccccccc}
\multicolumn{7}{c}{$(\%)$} \\
0,0 & $0 \mathrm{a}$ & $0 \mathrm{a}$ & $85^{\mathrm{a}}$ & $0 \mathrm{a}$ & $0 \mathrm{a}$ & $100 \mathrm{a}$ \\
0,5 & $0 \mathrm{a}$ & $0 \mathrm{a}$ & $85^{\mathrm{a}}$ & $0 \mathrm{a}$ & $0 \mathrm{a}$ & $100 \mathrm{a}$ \\
1,0 & $0 \mathrm{a}$ & $0 \mathrm{a}$ & $95^{\mathrm{a}}$ & $0 \mathrm{a}$ & $0 \mathrm{a}$ & $100 \mathrm{a}$ \\
2,0 & $0 \mathrm{a}$ & $0 \mathrm{a}$ & $100^{\mathrm{a}}$ & $0 \mathrm{a}$ & $0 \mathrm{a}$ & $100 \mathrm{a}$ \\
\hline
\end{tabular}

Médias seguidas pela mesma letra, na coluna, não diferem significativamente entre si pelo Teste de Tukey ao nível de 5\% de significância.

Para a percentagem de explantes de Anadenanthera macrocarpa regenerados, não foi verificada interação entre o tipo de segmento e as concentrações de BAP, indicando que os fatores apresentam independência. As maiores percentagens de explantes com brotações ocorreram em segmento cotiledonar tratado com $1 \mathrm{mg} \mathrm{L}^{-1}$ de BAP e no tratamento controle para os dois segmentos utilizados, não diferindo significativamente dos demais tratamentos (Figura 1).

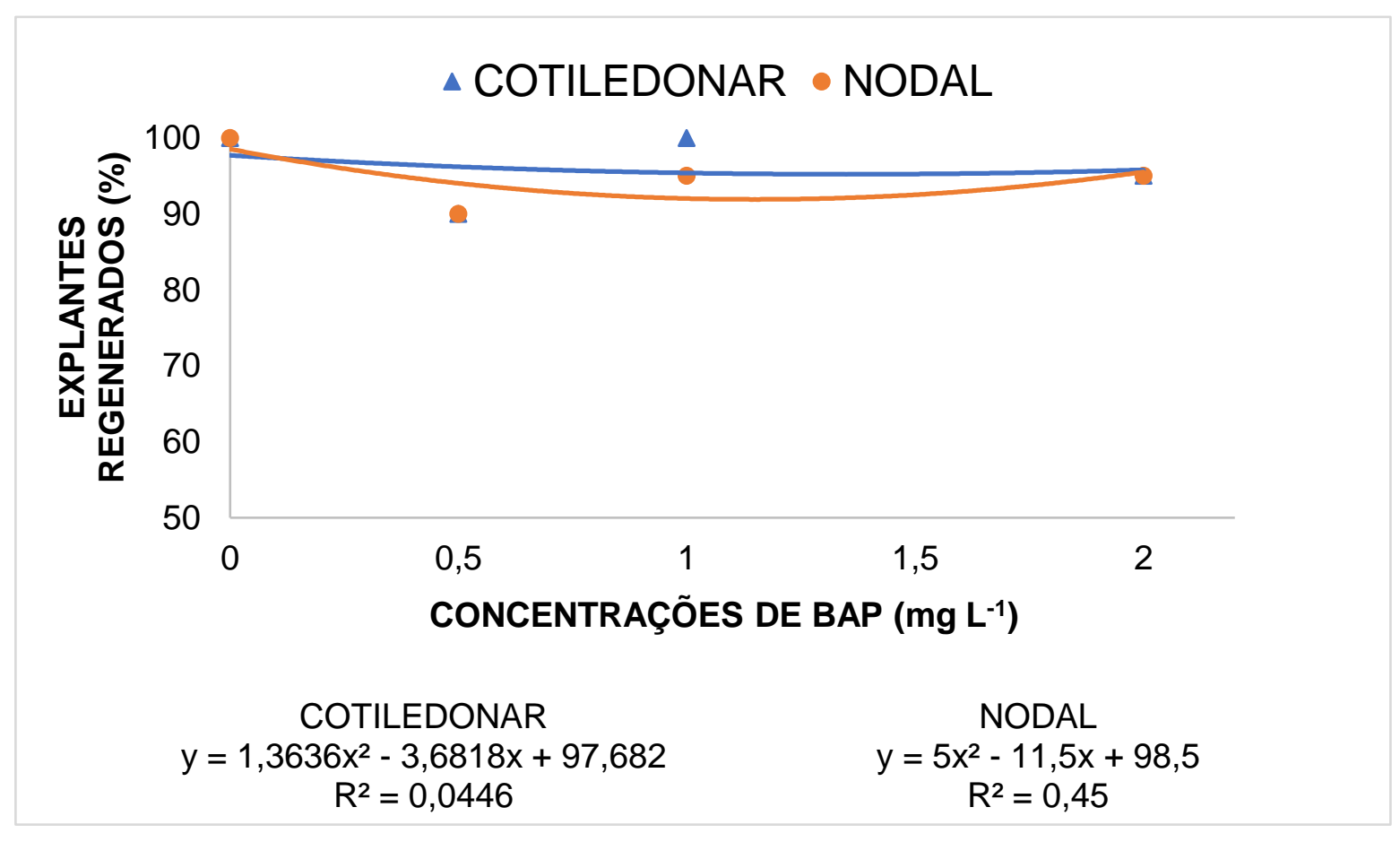

Figura 1. Percentagem de explantes regenerados após 30 dias de inoculados em meio MS suplementado com concentrações de BAP. 
A capacidade dos explantes formarem brotos, mesmo quando cultivados em meio livre de regulador vegetal, demonstra que não se faz necessário a utilização de uma fonte exógena de citocinina para estimular a indução de brotações nos segmentos cotiledonar e nodal de angico vermelho. Trabalhando com a regeneração in vitro de Parapiptadenia rigida, Kielse et al. (2009), observaram resultados semelhantes ao encontrado nesse estudo.

Quanto ao número de brotos, houve interação entre o tipo de segmento e as concentrações de BAP, indicando que os fatores não são independentes. O maior número de brotações por explante $(1,4)$ foi observado no tratamento utilizando o segmento cotiledonar tratado com $2 \mathrm{mg} \mathrm{L}^{-1}$ de BAP (Figura 2). Resultado divergente foi observado por Cordeiro et al. (2004) quando avaliaram diferentes concentrações de BAP na indução de brotações em segmentos nodais de paricá (Schizolobium amazonicum Huber ex Ducke - Fabaceae). Os autores verificaram que o tratamento com $3 \mathrm{mg} \mathrm{L}^{-1}$ BAP apresentou maior número de brotações $(2,14)$. No entanto, no presente estudo, foram avaliadas concentrações de BAP menores que $3 \mathrm{mg} \mathrm{L}^{-1}$, com isso, torna-se necessário a realização de novos estudos a fim de determinar concentrações mais adequadas para a espécie em estudo.

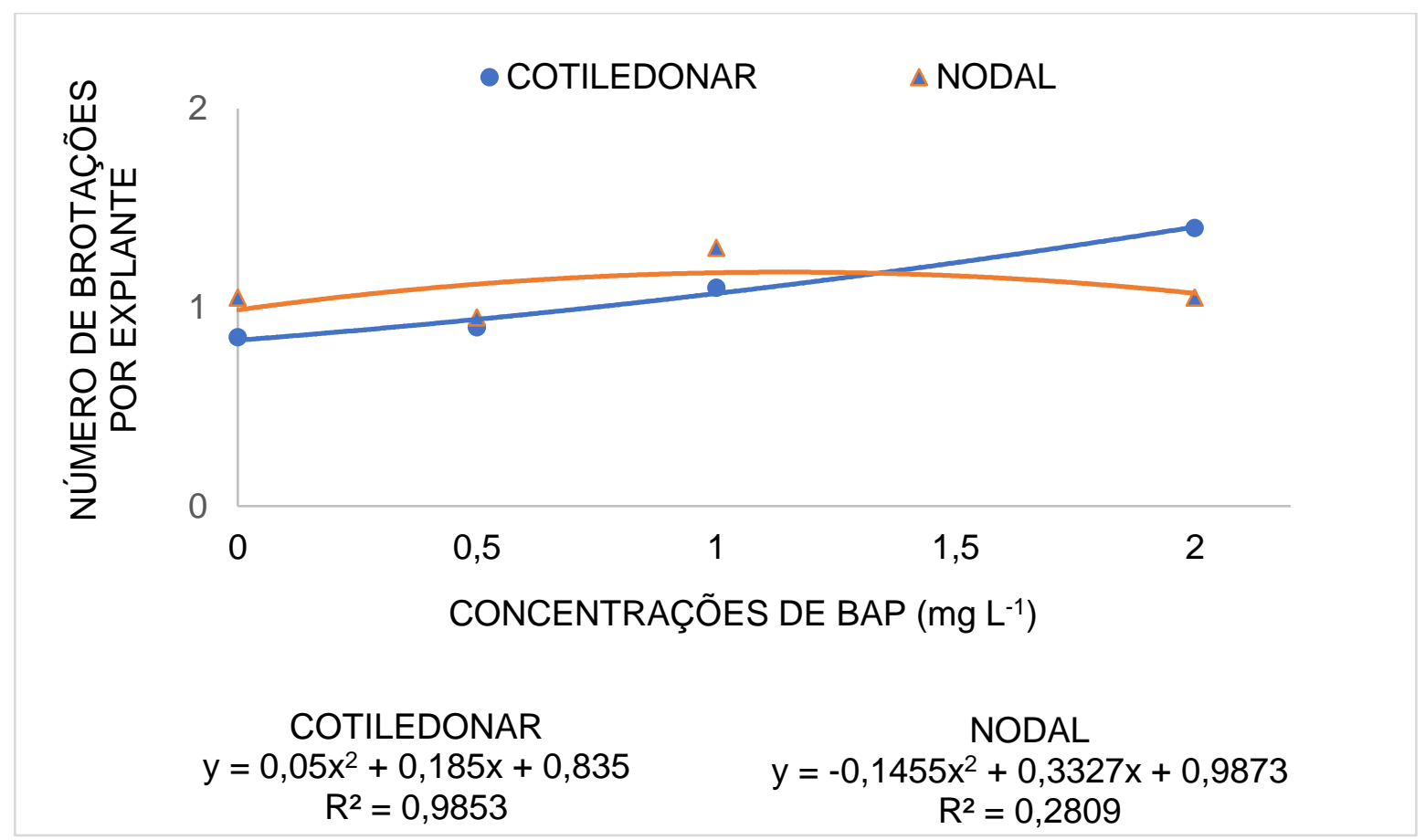

Figura 2. Número de brotações por explantes 30 dias após a inoculação de segmentos cotiledonar e nodal em meio MS suplementado com concentrações de BAP.

O efeito benéfico do BAP na multiplicação de brotações está relacionado com a influência deste regulador de crescimento vegetal na divisão celular e na liberação das gemas auxiliares inibidas pela dominância apical (Cordeiro et al., 2004).

Em relação ao número de gemas por brotação, houve uma tendência crescente de aumento até a concentração de $1 \mathrm{mg} \mathrm{L}^{-1}$ de BAP para o segmento cotiledonar, a qual apresentou o maior 
número de gemas por explante $(7,6)$, declinando em concentrações maiores. Já para o segmento nodal o maior número de gemas $(4,4)$ foi observado na concentração de $2 \mathrm{mg} \mathrm{L}^{-1}$ de BAP (Figura 3), o que indica uma variação na quantidade demandada dessa citocinina, de acordo com o tipo de segmento utilizado. Moura et al. (2012) estudando a multiplicação e alongamento in vitro de vinhático (Plathymenia reticulata), observaram resultados semelhantes para o segmento nodal, diferindo, entretanto, para o segmento cotiledonar que apresentou, também, uma tendência de crescimento do número de gemas à medida que a concentração foi aumentada.

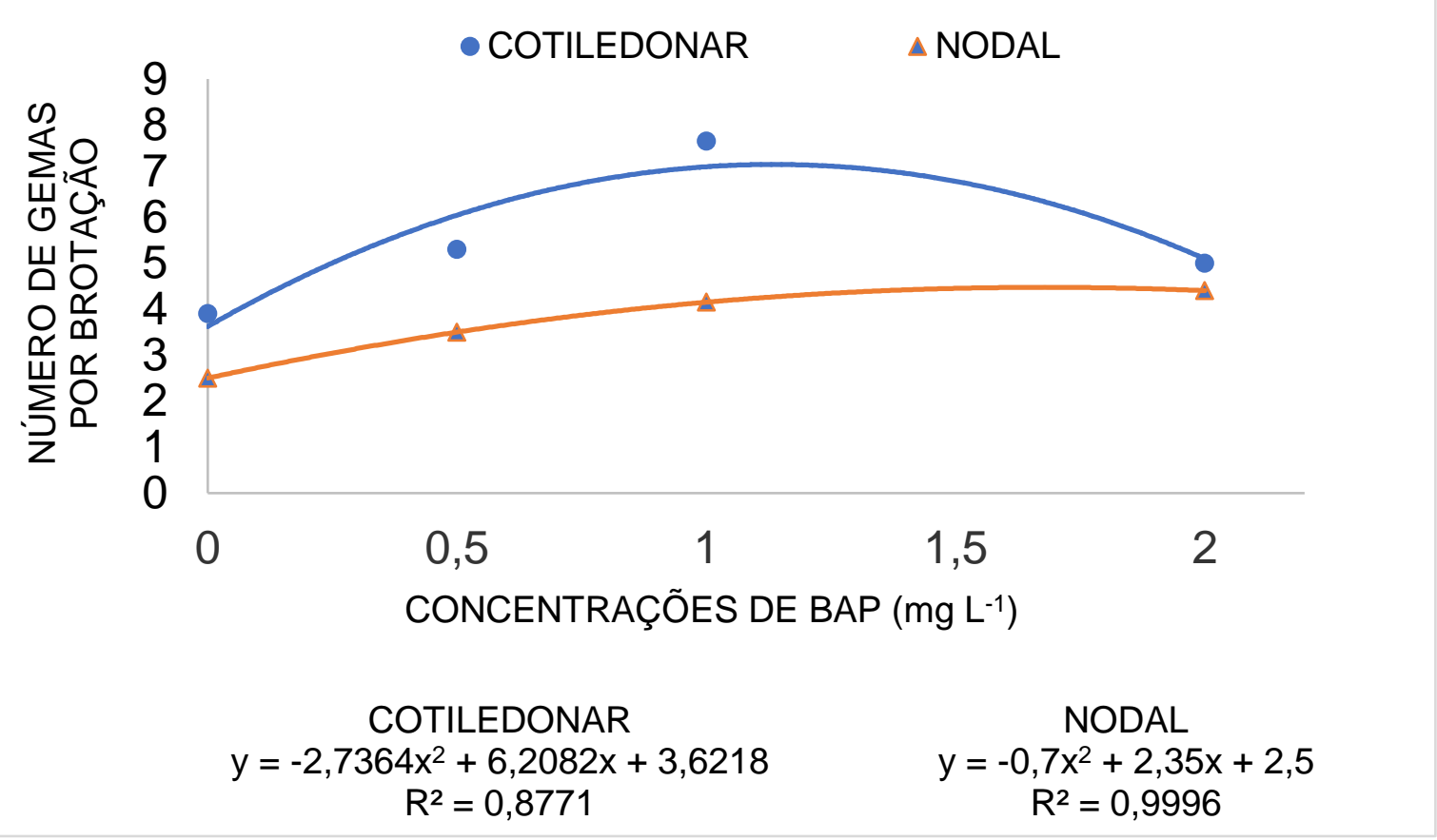

Figura 3. Números de gemas por brotação 30 dias após a inoculação de segmentos cotiledonar e nodal em meio MS suplementado com concentrações de BAP.

\section{CONCLUSÃO}

O uso de BAP aumentou a quantidade de brotações por explante regenerado. A concentração $2 \mathrm{mg} \mathrm{L}^{-1}$ de BAP proporcionou o maior número de brotações quando o segmento cotiledonar foi utilizado como explante.

\section{AGRADECIMENTOS}

À PICIN (Programa Institucional de Iniciação Científica) - UNEB pelo apoio financeiro e a equipe de pesquisa do Laboratório de Sementes e Laboratório de Biotecnologia, DTCS, UNEB, Campus III. 


\section{REFERÊNCIAS}

Cerdas, L.V.; Guzmán L. A. Organogénesis in vitro en Dalbergia retusa (Papilonaceae). Revista Biologica Tropical, 52(1), 41-46, 2004.

Cordeiro, I. M. C. C.; Lameira, O. A.; Ohashi, S. T. Efeito de BAP sobre a proliferação de brotos in vitro de Schizolobium amazonicum Huber ex Ducke (PARICÁ). Cerne, 10(1), 118-124, 2004.

Costa, G. M.; Nepomuceno, C. F.; Santana, J. R. F. Propagação in vitro de Erythrina velutina. Ciência Rural, 40(5):1090-1096. 2010.

Fehér, A.; Pasternak, T. P.; Dudits, D. Transition of somatic plant cells to an embryogenic state. Plant Cell, Tissue and Organ Culture, Netherlands, 74, 201- 228, 2003.

Figueiredo, G. S. Estabelecimento in vitro de marmeleiro japonês (Chaenomeles sinensis Koehne) cv Andramig I. 82 f. Dissertação (Mestrado em Ciências) - Universidade Federal de Pelotas, Pelotas. 2009.

Flores, R.; Stefanello, S.; Franco, E. T. H.; Manovani, N. Regeneração in vitro de espinheira-santa (Maytenus ilicifolia Mart.). Revista Brasileira de Agrociência, 4(3), 201-205, 1998.

George, E. F. Plant propagation by tissue culture; Part 1 the Technology. 2. ed. Edington: Exegetics Limited, 1993.

George, E. F. Plant tissue culture procedure background. In: George, E. F.; Hall, M. A.; Klerk, G. J. (Ed.). Plant propagation by tissue culture. The Netherland: Springers Internacional Publishing, 2008, p. 1-28.

Grattapaglia, D.; Machado, M. A. Micropropagação. In: Torres, A. C.; Caldas, L. S.; Buso, J. A. (Ed.). Cultura de tecidos e transformação genética de plantas. Brasília: EMBRAPA, 1999.

Hoppen, C. Efeito de diferentes fontes de fitorreguladores na morfogênese de diferentes procedências e explantes de Jatropha curcas I. cultivados in vitro. $130 \mathrm{f}$. Dissertação (Mestrado em Engenharia Florestal) - Universidade Federal do Paraná, Curitiba. 2011.

Kielse, P.; Franco, E. T. H.; Paranhos; J. T.; Lima, A. P. S. Regeneração in vitro de Parapiptadenia rigida. Ciência Rural, 39(4), 1088-1094, 2009.

Lorenzi, H. Árvores brasileiras: manual de identificação e cultivo de plantas arbóreas do Brasil. 4. Ed. São Paulo: Nova Odessa, p. 197, 2002.

Moura, L. C.; Titon, M.; Miranda, N. A.; Moreira, T. P.; Oliveira, M. L. R. Multiplicação e alongamento in vitro de vinhático (Plathymenia reticulata). Scientia Florestalis, 40(96), 499-505, 2012.

Murashige, T.; Skoog, F. A revised medium for rapid growth and bio assays with tobacco tissue cultures. Physiologia Plantarum, Copenhagen, 15, 473-497, 1962.

Pasqual, M. Culture Media. Universidade Federal de Lavras /FAEPE. Lavras - Minas Gerais (in Portuguese), 2001.

Pierik, R. L. M. Cultivo in vitro de las plantas superiores. Madrid: Editora Mundi Prensa Libros, 1990.

Rodrigues, M.; Paiva, R.; Nogueira, R. C.; Martinotto, C. E.; Silva Júnior, J. M. Morfogênese in vitro de nim a partir de explantes cotiledonares. Revista Árvore, 33(1), 21-26. 2009.

Silva, F. A. S. ASSISTAT: Versão 7.7. DEAG-CTRN-UFCG - Atualizado em 27 de junho de 2017. Disponível em: http://www.assistat.com. Acessado em: 20 de junho de 2020.

Skoog, F.; Miller, C. O. Chemical regulation of growth and orgam formation in plant tissue cultured in vitro. Simposium of the Society for Experimental Biology, London, 11, 118-1331, 1957.

Soomro, R.; Memon, R. A. Establishment ofe callus and suspension culture in Jatropha curcas. Pakistan Journal of Botany, 39(7), 2431-2441, 2007. 